\title{
BUYA HAMKA: KETELADANAN MULTITALENTA TANAH MELAYU NUSANTARA
}

\author{
Mahdi Bahar dan Hartati M. \\ Program Studi Seni, Drama, Tari, dan Musik, Fakultas Ilmu Budaya Universitas Jambi \\ bahar.mahdi@yahoo.com
}

Naskah diterima: 9 April 2019; direvisi: 5 Juni 2019; disetujui: 20 Juni 2019

\begin{abstract}
Abstrak
Buya HAMKA adalah tokoh Multi Talenta Nusantara banyak meninggalkan karya tulis, selain sebagai ulama, sastrawan, pendakwah, dan politikus. Sepanjang hayatnya senantiasa memperjuangkan ideologi berbasis ajaran tauhid. Suka dan duka, segudang pengalaman, pahit dan manis dijalani Buya HAMKA. Penghargaan demi pengahragaan diperolehnya, baik nasional maupun internasional. "Kebesaran" Buya HAMKA yang ditunjukkan melalui karya dan aktivitas semasa hidup, diteroka di tanah alam perjuangan mengisi kemerdekaan. Sekalipun perjuangan beresiko masuk penjara, namun akhirnya pemerintah Republik Indonesia menganugerahkan gelar Pahlawan Nasional kepada Buya HAMKA. Ketokohan Buya HAMKA merupakah anugerah yang patut ditauladani oleh para generasi di persada Nusantara.
\end{abstract}

Kata kunci: Hamka, karya, perjuangan,tauhid.

\begin{abstract}
Buya HAMKA is a multi-Talent Nusantara figure who left many writings, besides being scholars, writers, preachers and politicians. Throughout his life, he always fought for an ideology based on the teachings of Tawheed. Love and sorrow, a lot of experience, bitter and sweet lived by Buya HAMKA. He won awards for sports, both nationally and internationally. The "greatness" of the Buya HAMKA, which was demonstrated through work and activities during life, was explored in the natural lands of the struggle for independence. Even though the struggle risks entering prison, eventually the Republic of Indonesia government conferred the title of National Hero to Buya HAMKA. The character of Buya HAMKA is a gift that deserves to be followed by generations in the archipelago.
\end{abstract}

Keywords: Hamka, work, struggle, monotheism.

\section{PENDAHULUAN}

\section{"Harimau mati meninggalkan belang; \\ Gajah mati meninggalkan gading; \\ Manusia mati meninggalkan jasa;}

Besar harimau pada belangnya;

Besar gajah pada gadingnya;

Kebesaran manusia tampak pada karyanya..."
Si Bujang Jauah", "gelar" kesayangan sewaktu remaja diberikan Haji Rasul, Syeh Abdul Karim Amrullah ayah tercinta, tidak lagi di alam fana ini. Si Bujang Jauah telah meninggalkan kita, sekarang berada di alam kubur menuju Rabb-nya, yaitu Tuhan yang bergantung kepada-Nya segala sesuatu (Allahu samad). $\quad \mathrm{Si}$

${ }^{1} \mathrm{p}: / /$ hajibuyahamka.blogspot.com/200 9/07/ ; diunduh pkl. 4:50, tgl. 20-1-2015 
Bujang Jauah yang pada masa remaja suka berkelana ini, atas izin Allah SWT, sampai akhir hayatnya telah menjadi "besar" dan memang besar..., dengan "Multi Talenta" yang dianugerahkan oleh zat yang tidak perlu dipikirkan oleh manusia, ialah Allah 'azawajalla. Itulah beliau bernama Haji Abdul Malik Karim Amrullah yang disingkat HAMKA, diberi sebutan penghormatan dan kesayangan oleh ummat kepada beliau, yaitu "Buya HAMKA".

Atas kebesaran dan perjuangan yang ditunjukkan Buya HAMKA melalui buah pikir dan tindakan serta karya beliau untuk memajukan ummat, bangsa dan Tanah Air Indonesia berdasarkan pemikiran ke-Islaman yang beliau perjuangkan sebagai anak Melayu Nusantara yang dilahirkan di bumi Minangkabau, alhamdulillah berdasarkan Keputusan Presiden No. 113, Th. 2011, pemerintah Republik Indonesia menganugerahkan gelar Pahlawan Nasional kepada HAMKA. Oh.... Buya HAMKA, ... jasa dan perjuangan Buya untuk mencerdaskan ummat menuju "jalan yang lurus" (shiratal mustakim) insya Allah senantiasa akan kami kenang dan lanjutkan.

\section{Buya Sang Pahlawan Tauhid}

Sang pahlawan yang akrab dengan panggilan Buya HAMKA ini telah menunjukkan kepahlawanannya. Kepahlawanan itu telah "siang bak hari dan terang bak bulan" dalam bentuk buah pikir dan goresan kalamnya yang banyak disusun di bawah penerangan cahaya "lampu minyak tanah" dalam berbagai bidang ilmu pengetahuan dan juga seni, serta muatan dan kedalaman isinya yang tetap bernilai sepanjang masa. Sang pahlawan intelektual "menuju jalan yang lurus" bernama Buya HAMKA itu tidak hanya berhenti pada buah pikir yang direkam dalam bentuk karya tulis semata. Akan tetapi kemampuan itu diiringi oleh laku dan perbuatan, serta keteguhan yang beliau tunjukan sebagai pemimpin dan pelaku di berbagai ranah komunitas keahlian, sejalan dengan kepiawaian beliau sebagai pendakwah handal nan menyejukkan sanubari ummat di persada Nusantara.

Bertautan dengan itu amat tepat dan pantaslah terutama ketokohan serta kebesaran HAMKA di bidang ilmu keIslaman ('ulama) dan pendakwah yang disukai ummat ini, mengantarkan beliau kepada derajat yang dihormati secara 
kultural Melayu dengan sebutan "Buya". Pada sebutan Buya ini, sekaligus menempatkan HAMKA pada posisi penghormatan religius yang lazim dijadikan sebagai tolok ukur dan acuan dalam kehidupan sosial-budaya, khususnya dalam kebudayaan Melayu Minangkabau dan kebudayaan Melayu pada umumnya di bumi Nusantara.

\section{Kebesaran Buya HAMKA} sebagai 'ulama atau intelektual Islam yang tidak saja hanya besar melalui dan di berbagai mimbar, akan tetapi kebesaran itu beliau "abadikan" melalui keluasan dan kedalam yang menggambarkan kecerdasan sebagai seorang ahli tafsir Al-Quran dengan melahirkan Kitab Tafsir Al Azhar sebagai karya gemilang yang terdiri atas 30 juzu', yang dimulai menyusunnya oleh Buya HAMKA menjelang tahun 1960 pada masa alat penerang listrik masih langka di negeri ini; apalagi komputer, internet, atau telepon genggam (handphone) belum ada. Bahkan, karya utama dan terbesar beliau itu diselesaikan secara lengkap oleh pengarang dalam tahanan (penjara) pada masa pemerintahan Presiden Soekarno, karena dituduh melakukan kegiatan subversi terhadap pemerintah tanpa pernah dibuktikan secara hukum $^{2} \ldots$... Sungguh luar biasa...., jiwa dan jihad Buya mengungkap dan mengurai kebesaran serta kebenaran Allah, SWT., yang tertuang dalam Al Qur'an itu, dilakukan di penjara.

Mengutip apa yang disampaikan Prof. Dr. James Rush, guru besar sejarah pada Universitas Yale Amerika Serikat, sebagaimana ditulis pada bagian terakhir Kitab Tafsir Al Azhar Juzu' III seperti demikian. "Studi dan tulisan Hamka tentang kepercayaan dan pengetahuannya yang mendalam, tercermin secara dramatis dalam keberhasilannya menyusun Tafsir yang lengkap. Dan untuk masyarakat Indonesia yang sedang berkembang ia merupakan tiang penyangga. Ia mengharap agar masyarakat Indonesia menjadi masyarakat Islam, masyarakat yang aman, damai dan modern di Bawah Lindungan Ka'bah". 3 Oleh karena itu, kebesaran dan kepahlawanan Tauhid Buya HAMKA yang tampak dari usaha besar beliau sebagaimana terekam dalam karya Tafsir Al Qur'an tersebut, amat patut ditauladani dan dibumikan dalam dunia kependidikan.

\footnotetext{
${ }^{2}$ Hamka, Tafsir Al Azhar - Juzu' 3, (Jakarta: PT. Pustaka Panjimas, 1983), h. sampul akhir.

${ }^{3}$ Ibid.
} 
Sebagai pahlawan "Tauhid", dapat diyakini apa yang ingin dituju oleh Buya HAMKA. Terutama tujuannya adalah mewujudkan apa yang dijelaskan oleh Ismai'l Raji AlFaruqi dan Lois Lamya Al-Faruqi. Dua orang sarjana, pemikir, dan pemimpin yang tak kenal lelah mendakwahkan Islam sepanjang hayat mereka, terutama di Amerika Serikat. Mereka meninggal amat tragis, ... dibunuh dengan amat keji, ditikam dan disayat berkali-kali. Di antara tikaman itu mengenai jantung keduanya oleh orang yag tidak dikenal ${ }^{4}$. Mereka sepanjang hayat mengumandangkan dan berbicara di bumi "Paman Sam" itu tentang Tauhid sebagai prinsip pertama aksiologi dalam kehidupan Islam, seperti demikian.

"Tauhid menegaskan bahwa Tuhan telah menciptakan umat manusia agar manusia dapat membuktikan diri bernilai secara moral melalui perbuatannya. Sebagai Hakim agung dan akhir, Dia memperingatkan bahwa semua perbuatan manusia akan diperhitungkan; bahwa perbuatan baik mereka akan diberi pahala, dan perbuatan buruk mereka akan diberi hukuman. Tauhid selanjutnya menegaskan bahwa Tuhan menempatkan manusia di muka bumi agar manusia mendiaminya. Agar

\footnotetext{
${ }^{4}$ Ismai'I Raji Al-Faruqi dan Lois Lamya Al-Faruqi, Atlas Budaya Islam: Menjelajah Khazanah Peradaban Gemilang, Cetakan ke-IV, Terj. Ilyas Hasan dari judul The Cultural Atlas of Islam, (Bandung: Mizan, 2003). H. 5.
}

manusia dapat bekerja di atas bumi, memakan buah-buahannya, menikmati kebaikan dan keindahannya, dan memakmurkan bumi dan dirinya. Inilah penegasan-dunia: menerima dunia karena dunia tidak berdosa dan baik, diciptakan oleh Tuhan dan diatur olehNya untuk dimanfaatkan manusia."

$$
\text { Intelektualitas Buya HAMKA }
$$

tidak hanya tercatat di bidang studi keIslaman yang intinya adalah "Mengagungkan Ketauhidan", namun beliau adalah seorang pujangga berjuang lewat untaian kata-kata sastra. Rangkaian kata diekspresikan bak susunan anak tangga menuju puncak untuk mengantarkan pembaca pada pencapaian idealisme berbasis ajaran Tauhid yang beliau teropongkan pada kehidupan sosial saat itu. Keindahan susunan kata dialur dan dialirkan melalui berbagai kelokan hayatan, namun tetap mampu membawa pembaca pada pemaknaan (meaning of meaning) yang beliau selubungkan di balik yang kasat mata itu. Kesenjangan antara yang ideal dan yang faktual, sebagaimana kondisi kontemporer yang beliau lihat, menjadi kegundahan yang inspiratif dan memunculkan daya imajinatif, serta mampu beliau tuangkan secara kreatif menjadi karya sastra yang mengangumkan. Seperti

${ }^{5}$ Ibid, h. 119 
diketahui karya sastra beliau yang terkenal adalah "Tenggelamnya Kapal Van der Wijck (1) dan Di Bawah Lindungan Ka'bah (2)", 6

Sinopsis (1):

"Novel ini bercerita tentang kisah cinta dua insan, tapi dipisahkan oleh tradisi adat. Ada dua adat yang ada dalam novel ini yaitu Budaya Minangkabau (Padang) dan Budaya Bugis (Makassar). Sang penulis Buya Hamka beranggapan bahwa beberapa tradisi adat tersebut tidak sesuai dengan dasar-dasar Islam ataupun akal budi yang sehat" 7

Sinopsis (2):

"Seorang pemuda bernama Hamid, sejak berumur empat tahun telah ditinggal mati ayahnya. Ayah Hamid mula-mula ialah seorang yang kaya. Karena itu banyak sanak saudara dan sahabatnya. Tetapi setelah perniagaannya jatuh dan menjadi melarat, tak ada lagi sanak saudara dan sahabatnya yang datang. Karena sudah tak terpandang lagi oleh orang-orang sekitarnya itu, maka pindahlah ayah Hamid beserta ibunya ke kota Padang, yang akhirnya dibuatnya sebuah rumah kecil. Di tempat itulah ayah Hamid meninggal". 8

Dari beberapa karya sastra beliau, amat tampak betapa budaya lingkungan tempat beliau dilahirkan, yaitu tanah Melayu Minangkabau dengan adatnya yang belum sempurna dilaksanakan bersendikan syarak, dan

\footnotetext{
${ }^{6}$ http://id.wikipedia.org/wiki;

diunduh: pkl. 9:18, tgl. 20-1-2015.

${ }^{7}$ http://indosastra.com/sinopsis;

diunduh: pkl. 10:18, tgl. 23-1-2015.

${ }^{8} \mathrm{http}: / /$ www.pustakasekolah.com/sino

psis; diunduh: pkl. 10:38, tgl. 23-1-2015.
}

berbagai ketimpangan yang terjadi tidak sebagaimana yang dikehendaki ajaran Tauhid, menjadi inspirasi bagi Buya HAMKA untuk dilahirkan kedalam karya sastra. Melalui karya sastra itulah, "Orang Tua" kita ini berjuang bak pahlawan dengan senjata pena, berkeinginan agar semua orang dapat diarahkan menuju "jalan yang lurus". Cukup banyak karya sastra yang beliau lahirkan sebagai saluran kejuangan dan kepahlawanan Buya HAMKA yang takkan pernah padam memperjuangkan umat untuk senantiasa berada pada jalan yang benar.

Lihat saja puisi heroik yang beliau toreskan tanggal 13 November 1957 setelah mendengar pidato $\mathrm{M}$. Natsir yang mengurai kelemahan system kehidupan buatan manusia. HAMKA dengan tegas menawarkan kepada Sidang Konstituante agar ummat Islam bebas menjalankan syari'at Islam bagi pemeluknya dalam Negara Kesatuan Republik Indonesia. Semangat ke-Tauhidan HAMKA yang demikian terabadikan dalam puisi beliau berikut:

KEPADA SAUDARAKU M.NATSIR

Meskipun bersilang keris di leher Berkilat pedang di hadapan matamu Namun yang benar kau sebut juga benar Cita Muhammad biarlah lahir 
Bongkar apinya sampai bertemu

Hidangkan di atas persada nusa

Jibril berdiri sebelah kananmu

Mikail berdiri sebelah kiri

Lindungan Ilahi memberimu tenaga

Suka dan duka kita hadapi

Suaramu wahai Natsir, suara kaum-mu

Kemana lagi, Natsir kemana kita lagi

Ini berjuta kawan sepaham

Hidup dan mati bersama-sama

Untuk menuntut Ridha Ilahi

Dan aku pun masukkan

Dalam daftarmu......!

(dikutip dari buku "Mengenang 100

tahun HAMKA")

Selanjutnya M. Natsir membalas dengan sajak pula pada Buya HAMKA, berjudul DAFTAR, demikian.

\section{DAFTAR}

\section{Saudaraku Hamka,}

Lama, suaramu tak kudengar lagi

Lama...

Kadang-kadang,

Di tengah-tengah si pongah mortir dan

mitralyur,

Dentuman bom dan meriam sahut-

menyahut,

Kudengar, tingkatan irama sajakmu itu, Yang pernah kau hadiahkan kepadaku,

Entahlah, tak kunjung namamu bertemu di dalam "Daftar".

Tiba-tiba,

Di tengah-tengah gemuruh ancaman

dan gertakan,

Rayuan umbuk dan umbai silih

berganti,

Melantang menyambar api kalimah hak dari mulutmu,

Yang biasa bersenandung itu,

Seakan tak terhiraukan olehmu bahaya mengancam.

Aku tersentak,

Darahku berdebar,

Air mataku menyenak,

Girang, diliputi syukur

Pancangkan!

Pancangkan olehmu, wahai Bilal!
Pancangkan Pandji-pandji Kalimah

Tauhid,

Walau karihal kafirun...

Berjuta kawan sefaham bersiap masuk

Kedalam "daftarmu" ... *9

Betapa terang benderangnya

kepahlawanan Tauhid yang disuarakan Buya HAMKA melalui untaikan katakata sastrawi yang bernilai abadi di bumi ini, memantaskan beliau sebagai seorang pujangga yang pahlawan. Daya imajinasi yang tinggi, kemampuan pemilihan kata yang tajam dan luar biasa, bermuatan makna yang sangat dalam, menggelorakan semangat kejuangan nan heroik, menyusun alur pikiran dalam goresan dan garisan karya sastra, merupakan kemampuan yang menyatu dengan kehidupan Buya HAMKA. Demikian Buya HAMKA, apa yang dilihat dan dirasakan senjang antara yang ideal dengan yang faktual dalam konteks ke-Tauhidan yang qaffah, sebagaimana beliau ungkapkan dalam puisi "KEPADA SAUDARAKU M. NATSIR", itu merupakan konsistensi Buya HAMKA memperjuangkan tujuan hidup beliau, sebagaimana digoreskan di akhir karangannya berjudul "Ajahku" pada bulan April tahun 1943: "Dimana-

${ }^{9}$ https://serbasejarah.wordpress.com; diunduh: pkl. 2:55, tgl. 23-1-2015. 
mana, namun kebenaran hendaklah

ditegakan". ${ }^{10}$

\section{HAMKA Dalam Karier}

Tidak saja sosok Buya HAMKA sebagai 'ulama dan pujangga, masih banyak lagi kepakaran dan pengalaman yang beliau punyai dan geluti sebagai karier. Sebagai seorang ahli tasauf, Buya HAMKA telah dikukuhkan sebagai Guru Besar Ilmu Tasauf di Perguruan Tinggi Agama Islam Negeri (PTAIN) Yogyakarta tahun $1958^{11}$; sebagai pendakwah dan 'ulama, beliau mendapat anugerah gelar Doktor Honoris Causa dari Univ. al-Azhar, Kairo; sebagai sastrawan, beliau mendapat gelar Doktor Honoris Causa dari Univ. Kebangsaan Malaysia dan gelar Profesor dari Univ. Prof. Moestopo, Jakarta; sebagai pimpinan dan aktif dalam organisasi, Buya HAMKA pernah memimpin organisasi Muhammadiyah, rektor Perguruan Tinggi Islam Jakarta dan Univ. Prof. Mustopo Jakarta, Ketua Umum Majlis Ulama Indonesia; sebagai pelaku politik, Buya HAMKA aktif dengan Partai Masyumi dan pada pemilihan umum tahun 1955 beliau terpilih

\footnotetext{
${ }^{10}$ Hamka, Ajahku - Cetakan Ketiga, (Djakarta: Djajamurni, 1963). H. 302.

${ }^{11}$ Hamka, Tasauf: Perkembangan dan Pemurniannya, (Jakarta: Pustaka Panjimas, 1984). H. Pengantar Penerbit.
}

menjadi anggota Dewan Konstituante; selain dari itu Buya HAMKA juga aktif sebagai wartawan, editor berbagai majalah dan pemimpin Majalah; peneliti yang berpengalaman; sejarahwan; dan budayawan"12. "Hamka memang sudah hampir tidak berarti "golongan" agama. Juga tidak hanya seorang "kiai". Barangkali memang inilah ulama pertama yang dipunyai Indonesia, yang sangat paham "hidup di luar masjid". 13

Kebesaran Buya HAMKA tidak saja di "Masjid" akan tetapi juga besar dan dihormati di "Luar Masjid". Sang "Multi Talenta" anak Melayu Nusantara yang dilahirkan di Ranah Minangkabau ini banyak meninggalkan jejak yang terlalu mahal untuk diabaikan. Oleh karena itu, menjadi keniscayaan dilakukan penggalian nilai-nilai postif dari jejak dan langkah Buya HAMKA untuk disuri-tauladankan ke dalam berbagai kemungkinan dunia pendidikan, sehingga tumbuh HAMKAHAMKA yang baru untuk membangun ummat, bangsa dan negara, yang dapat dipertanggungjawabkan kebenaran laku dan perbuatannya di pengadilan Allah,

\footnotetext{
${ }^{12}$ Lihat, al. Hamka, Islam dan Adat Minangkabau, (Jakarta: PT. Pustaka Panjimas, 1984). Passim.

${ }^{13}$ https://serbasejarah.wordpress.com; diunduh: pkl. 2:55, tgl. 23-1-2015.
} 
SWT. Seratusan lebih buku yang beliau pusakakan untuk kita dan berbagai pengalaman yang dipunyai Buya HAMKA, serta penghargaan yang diperoleh dari lembaga terhormat, baik nasional maupun internasional merupakan gambaran prestasi multi karier. Semua itu patut dijadikan pemicu dan pacu, sehingga hadir dalam diri sebagai "tunjuk ajar" yang patut ditauladani dalam membangun hidup.

\section{Pemikiran HAMKA Dalam Tinjauan}

"Tulis Baca"

Kepiawaian Buya HAMKA dalam tulis baca, yang lahir dari berbagai latar situasi dan kondisi sosial, budaya, serta politik di sepanjang hayatnya, telah melahirkan seratusan lebih karya tulis dalam sejumlah ranah, antara lain: agama, sastra, politik, budaya, dan sejarah. Karya-karya ini terabadikan sampai saat ini, "tidakkan lapuk karena hujan, tidakkan lekang karena panas". Goresan tinta di kertas "buram" berjalan perlahan tapi pasti sepanjang hayatnya, telah menorehkan pemikiran yang brillian, cerdas, tajam, dan kontemplatif yang mencerahkan dari Sang Maha Guru..., Buya HAMKA. Pemikiran mendasar (filosofis) dan hasil kajian yang cerdas dalam banyak bidang ilmu yang lahir dari Buya HAMKA senantiasa hidup dan relevan sepanjang masa. Katakanlah misalnya bagaimana kesenjangan hak dalam kehidupan yang seharusnya tidak memunculkan masalah mendasar disebabkan oleh perbedaan latar budaya antara seseorang (Hayati) berlatar budaya Minangkabau dengan seseorang (Zainuddin) berlatar budaya Bugis-Makasar, meskipun ayahnya orang Minangkabau seperti terlukis dalam karya "Tenggelamnya Kapal Van der Wijck". Dalam pandangan Buya HAMKA, kesenjangan hubungan persaudaraan disebabkan oleh sistem kekerabatan yang tidak seharusnya terjadi pada diri Zainuddin, merupakan kultur yang tidak sesuai dengan dasardasar Islam, ataupun akal budi yang sehat.

Bagaimanapun kuatnya azas sosial-budaya sistem matrilineal mengungkung kehidupan yang diwarisi secara turun temurun dalam bingkai budaya Minangkabau, namun ketidak pantasan yang dilihat Sang Buya berasaskan ajaran tauhid ataupun akal budi yang sehat, tetap disuarakannya meskipun dalam situasi dan kondisi pendukung adat Minangkabau yang amat kental pada masa itu di kalangan 
ninik-mamak dan orang Minangkabau pada umumnya. Begitu pula pemikiran kritis dan heroik yang dilancarkan menyuarakan kebenaran ajaran tauhid untuk mewujudkan bangsa dan negara yang ideal menurut HAMKA yang terabadikan dalam puisi "DAFTAR" ditulis M. Natsir untuk dirinya seperti ternukil di atas; meskipun "Di tengahtengah gemuruh ancaman dan gertakan, Rayuan umbuk dan umbai silih berganti, Melantang menyambar api kalimah hak dari mulutmu, Yang biasa bersenandung itu, Seakan tak terhiraukan olehmu bahaya mengancam....Pancangkan olehmu, wahai Bilal !, Pancangkan Pandjipandji Kalimah Tauhid, Walau karihal kafirun...". Pemikiran hakiki dan inspiratif bernilai dasar tersebut, niscaya akan abadi melaui tulis baca. Amat mulyalah ajaran Islam pertama kali diturunkan kepada Nabi Muhammad, SAW tentang perintah membaca (iqra'), "Bacalah dengan (menyebut) nama Tuhanmu Yang menciptakan" ${ }^{\text {.14 }}$ Demikian tulis baca sebagai azas yang akan memainkan peran dalam membangun hidup dan peradaban.

Apa yang dilakukan Buya HAMKA terutama dalam bentuk karya

${ }^{14}$ Al-Qur'an, S, 96:1 tulis baca ini dapat dilihat sebagai salah satu ciri penunjuk kemajuan peradaban (civilization) yang mencerdaskan di planet bumi. Sebagai perbandingan dapat dilihat dari salah satu dasar bangunan awal Eropa modern pada kurun waktu 1460-1559, seperti dikemukakan Eugene F. Rice, Jr. $(1970)^{15}$, yaitu penemuan (invention) “alat pencetakan" (printing) oleh tiga nama yang menonjol pada waktu itu, ialah Johann Gutenbergh (1395-1468), Johann Fust (1400-1465), dan Peter Schöffer (1425-1502) di Mainz baratdaya Jérman. Namun demikian, kemajuan bidang teknologi kepenulisan penemuan Eropa tidaklah berdiri sendiri, akan tetapi merupakan gabungan dari dua penemuan bangsa Cina sebelumnya, yaitu kotak pencetak (block printing ${ }^{16}$ ) dan kertas, pada awal abad ke-8. Selanjutnya, pencetakan kertas di Eropa diawali di Spanyol pada abad ke-12 oleh orang-orang (migran) Arab, yang menerima sendiri teknologi pencetakan kertas dari Cina. Kemudian secara perlahan, dua abad setelah itu, berkembang pencetakan kertas di dataran Eropa, yaitu Italy (1270),

\footnotetext{
${ }^{15}$ Eugene F. Rice, Jr., The Foundations of Modern Europe, i460-1559, (New York: W.W. Norton \& Company, 1970), pp. 1-23.

${ }^{16}$ Kotak pencetak tersebut terbuat dari kayu.
} 
Perancis (1340), Jerman (1390), dan

Swis (1411). Berdasarkan penemuan alat tulis berupa "mesin" pencetak dan kertas tersebut, maka terjadi perubahan sejarah, yaitu pencepatan kemajuan informasi dan komunikasi yang sebelumnya bergerak amat lambat dalam bentuk tradisi lisan (oral tradition) ke bentuk tradisi tulis baca.

Dampak kemajuan tulis baca menggunakan teknologi pencetakan tersebut, menjelang tahun 1500 ialah, percetakan-percetakan di dataran Eropa (Barat) telah menerbitkan enam juta buku dalam bentuk kurang lebih lima puluh ribu edisi. Melalui buku-buku tersebut, informasi ilmu dan atau pengetahuan berkembang pesat, sehingga para pedagang, seniman, pengacara, kantor-kantor pemerintahan, dokter, dan guru yang tinggal dan hidup di kota-kota daratan Eropa pada umumnya, amat memerlukan bukubuku.

Demikian pula tiga pilar utama yang membangun peradaban (saintifik) Eropa modern, yaitu matematik, logika, dan eksperimen, yang juga merupakan gabungan dari penemuan-penemuan bangsa lain sebelumnya, menjadi amat cepat tersebar informasinya, sehingga menjadi inspirasi bagi banyak orang untuk pengembangan ilmu pengatahuan yang lain. Amat benarlah, bahwa tulis baca adalah kunci peradaban manusia yang mencerdaskan, disebabkan tulis baca tidak saja sebagai sarana atau media penyampaian ilmu dan atau pengetahuan, akan tetapi tulisan sebagai suatu entitas dapat "mengabadikan" ilmu dan atau pengetahuan dari suatu zaman ke zaman berikutnya. Oleh karena itu, pada satu sisi, karya tulis juga berperan sekaligus sebagai dokumen ilmu atau pengetahuan tertentu, yang sewaktu-waktu dapat dijadikan rujukan untuk membangun perilaku. Di antara kebesaran Buya HAMKA tergambar dari seratusan lebih karya tulis dalam bentuk buku yang beliau karang sepanjang hayatnya.

Apa bila ditelusuri lebih jauh berdasarkan pandagan fenomenology Edmun Husserl (founder of phenomenology, 1931), sesungguhnya pengetahuan manusia itulah pada hakikatnya yang menentukan perilaku manusia (behavioral aspects); manusia tidak akan bisa berbuat di luar pengetahuannya. Manusia hanya akan berbuat berdasarkan atau sesuai (kehendak) dengan pengetahuannya. Kenyataan empirik atas peran tulis baca yang seperti demikian, terutama di 
daratan Eropa pada pertengahan abad ke-15 sampai pada pertengahan abad ke-16, dapat dijadikan bukti kebenaran ajaran Islam yang menempatkan tulis baca sebagai bagian dari sistem ajarannya; (1) Bacalah dengan (menyebut) nama Tuhanmu Yang menciptakan; (3). Bacalah, dan Tuhanmulah Yang Maha Pemurah; (4) Yang mengajar (manusia) dengan perantaraan kalam [tulis baca]; (5). Dia mengajar kepada manusia apa yang tidak diketahuinya. ${ }^{17}$ Ayat ini pada dasarnya dapat dilihat, betapa Allah, SWT Yang Maha Pencipta telah mempersiapkan Islam sebagai agama yang sempurna. Terlihat dari sifat futuristiknya berupa perintah "membaca" (tulis baca) yang tidak bisa dipungkiri eksistensinya merupakan tonggak bangunan kehidupan modern.

Bukti kebenaran ajaran ini, sebagaimana terjadi dalam kemajuan peradaban Eropa sekira lima ratus sembilan belas tahun yang lalu dan pada akhirnya mendunia tersebut, sekaligus dapat dijadikan pembenaran dari apa yang diajarkan oleh Islam. Tulis baca dengan tegas dinyatakan oleh Islam merupakan media pembelajaran untuk mewujudkan kecerdasan manusia dari

\footnotetext{
${ }^{17} \mathrm{Al}-\mathrm{Qur}$ an, S. 96: 1,3,4,5.
}

tidak tahu menjadi tahu. Islam mengajarkan, bahwa tulis baca sebagai salah satu bagian dari kehidupan manusia, sebagaimana kehidupan manusia modern dicirikan oleh kemampuan tulis baca, adalah sesuatu yang hakiki dalam keberlangsungan hidup manusia yang diabadikan sebagai bagian dari ajaran Islam. Dalam hal ini, Islam menjadikan tulis baca sebagai media pengajaran untuk menyampaikan pengetahuan dari suatu manusia kepada manusia yang lain.

Berdasarkan ajaran tulis baca yang suci dan mutlak benarnya tersebut, dapat ditelusuri secara struktural, ada tiga faktor yang terkandung di dalamnya, yaitu ajaran (pengetahuan), tulisan, dan baca. Ketiga faktor ini, terlahir dalam satu kesatuan bentuk sistem tulis baca. Masing-masing bagian bergerak secara sistemik untuk mencapai suatu tujuan, yaitu tersampaikan kabar (information) gembira atau kabar pertakut kepada manusia. Selanjutnya dapat dijelaskan, yaitu: pertama, ajaran ditempatkan sebagai isi (contents) dan merupakan substansi (gist of meaning) dari sesuatu yang dimaksud; ia terkategori pada salah satu bentuk pengetahuan, yaitu sesuatu yang diketahui, sehingga 
esensinya bersifat immaterial. Kedua, adalah tulisan, yaitu fenomena material, ia berupa "words or other symbols such as hieroglyphics written down as a means of communication"18. Ketiga, ialah baca, yaitu bentuk perilaku berupa kemampuan membaca apa yang ditulis ("qalam"). Tiga aspek ini menjadi fondasi yang abadi secara empirik (touchable) dalam kehidupan dan keberlangsungan Islam sebagai salah satu lembaga kehidupan manusia, yang terwujud kedalam bentuk buku (kitab) bernama al-Qur'an('bacaan”) sejalan dengan Sunnah Rasul berupa hadis.

$$
\text { Al-Qur'ansebagai wujud }
$$

lahiriah dari bentuk sistem tulis baca seperti demikian, berperan sebagai waduk pengetahuan yang bersifat normatif dalam bentuk ajaran. Ajaran itu "tersurat" dalam tulisan Arab yang disusun dalam bentuk kitab, bernama Al-Qur'an. Dalam hal ini, Islam (Allah, SWT) telah memilih dan menetapkan aksara Arab sebagai media tulis. Pilihan tersebut sejalan dengan keberadaan Nabi Muhammad, SAW sebagai manusia yang hidup berbahasa dan berkebangsaan Arab. Tulisan dan bahasa Arab yang terpilih dan

\footnotetext{
${ }^{18}$ Microsoft $^{\circledR}$ Encarta $^{\circledR}$ 2006. (C) 19932005 Microsoft Corporation. All rights reserved.
}

ditetapkan Allah, SWT seperti demikian, digunakan sebagai media informasi untuk manusia. Pada masa awal Islam, informasi dan komunikasi ke-Islaman ditujukan atau berlangsung terutama bagi mereka kaum Nabi Muhammad, SAW sendiri, sebagaimana dinyatakan Allah, SWT "Kami tidak mengutus seorang rasulpun, melainkan dengan bahasa kaumnya, supaya ia dapat memberi penjelasan dengan terang kepada mereka"19.

Ajaran-ajaran yang disampaikan melalui bahasa Arab tersebut diabadikan ke dalam bentuk tulisan Arab yang dikodifikasikan dalam bentuk kitab. Ia merupakan dokumen Islam dan bahkan satu-satunya karya (seni) tulis baca Islam yang tak tertandingi oleh manusia, sebabnya ialah; "Tidaklah mungkin al-Qur'an ini dibuat oleh selain Allah, SWT"20. Berdasarkan kenyataan seperti demikian, sesungguhnya pada satu sisi, eksistensi Al-Qur'an sebagai karya tulis baca, dapat dijadikan model bagi manusia untuk membangun kehidupan tulis baca, sehingga ia jadi bagian dari peradaban dan sekaligus sebagai alat

\footnotetext{
${ }^{19}$ Al-Qur'an, S, 14: 4.

${ }^{20}$ Al-Qur'an, S, 10: 37.
} 
ukur kemajuan kecerdasan serta peradaban manusia atau bangsa.

Tiga faktor utama yang membangun sistem tulis baca dan terwujud dalam bentuk kitab bernama Al-Qur'an sebagaimana dibicarakan di atas, yaitu terdiri atas ajaran atau isi (contents), tulisan, serta baca tersebut, dapat djadikan model dalam membangun kemampuan tulis baca. Pertama, aspek ajaran adalah isi yang hendak disampaikan, yaitu berupa pengetahuan (wahyu) yang mutlak benarnya. Dalam konteks ini dapat dilihat, yaitu terkandung adanya suatu kebenaran, kejujuran, keadilan, ketegasan, menyejukan, kejelasan, mencerdaskan, inspiratif, dsb., yang inti semuanya adalah sebagai pedoman kehidupan; itulah hakikat dari isi yang seyogiyanya diwujudkan dalam membangun sistem kepenulisan. Pada al-Qur'an, isi tersebut sebagai “petunjuk bagi orang yang bertaqwa",21. Dalam hal ini, isi hendaklah bersifat mencerdasakan, yaitu menuju ke arah kehidupan yang lebih baik.

$$
\text { Buya HAMKA telah }
$$
mewujudkan isi tersebut dalam bentuk pemikiran yang mendasar, dan dalam (filosofis), serta inspiratif, dalam

\footnotetext{
${ }^{21} \mathrm{Al}-\mathrm{Qur}$ 'an, S, 2: 2.
}

berbagai karya tulisnya. Di antaranya dapat dilihat betapa pandangan dan kritik Buya HAMKA yang mendasar terhadap kesenjangan hidup yang dialami Zainuddin beribu BugisMakasar dan ayah berdarah Minang. Zainuddin tidak dipandang sebagai orang Minang oleh keluarga ayahnya meskipun ayah Zainuddin orang Minang, seperti dilukiskan dalam karya "Tenggelamnya Kapal Van der Wijck". Pandangan dan pemikiran kritis Buya HAMKA atas kesenjangan budaya (adat) seperti demikian merupakan pengatahuan yang bernas sebagai isi dari tulisan, dan akan tersurat dalam keabadian sepanjang masa.

Aspek kedua adalah tulisan, yaitu media untuk menyampaikan isi. Pada dasarnya ada dua model kemasan isi (ayat), yaitu ayat-ayat yang diturunkan di Makkah dan ayat-ayat yang diturunkan di Madinah. Ayat-ayat yang diturunkan di Makkah pada umumnya pendek-pendek dan ayat-ayat yang di turunkan di Madinah panjangpanjang; keduanya berbingkai sastra ilahiyah yang tak berhingga. Dapat diambil pengertian di sini ialah, ayatayat Makkiyah menyuratkan ajaran dalam bentuk tulisan "ringkas" atau pendek-pendek, sehingga tidak 
memerlukan pemahaman yang "tinggi" atau penafsiran yang "dalam" untuk mengetahui maksudnya. Secara semiotik dapat dijelaskan, yaitu pesan yang disampaikan mudah dipahami, karena ia berada terutama pada tingkatan arti (meaning). Siapa saja yang membaca atau mendengarkan, akan mudah memahami apa arti yang disampaikan melalui tulisan (ayat) tersebut.

Model ayat-ayat Madaniah adalah panjang-panjang. Model kemasan ayat ini banyak memerlukan pemahaman yang mendalam untuk dapat mengetahui apa maksud atau makna yang terkandung dalam teks atau ayat tersebut. Pada tingkatan ini, adakalanya maksud yang terkandung pada teks berada pada tingkatan makna (meaning of meaning). Berarti di sini ialah, pembacanya adalah orang-orang yang telah memiliki kemajuan ilmu atau pengetahuan tingkat tertentu, sehingga dengan cara yang lebih "cerdas" seperti demikianlah informasi dikemas karena dipandang cocok untuk mereka pembaca, yaitu orang-orang Madinah.

Dua kemungkinan dasar model kepenulisan seperti demikian, niscaya memerlukan keterampilan tertentu untuk mewujudkannya. Dalam hal ini, seseorang dituntut memiliki keterampilan kepenulisan sebagaimana kemungkinan model tulisan itu sendiri, yang dapat diterjemahkan dalam kehidupan sekarang dengan segala kemajuan yang dihadapi. Pada sisi lain, kedua aspek di atas seyogiyanya terwujud dalam bentuk pernyataan yang menarik dan dikemas kedalam tulisan seindah mungkin. Buya HAMKA telah melakukan bentuk tulisan seperti demikian sebagaimana terabadikan dalam seratusan lebih karya tulisnya, terutama karya-karya sastra dan karya tulis yang lain berpaparan mudah dibaca dan dipahmi, menarik, serta mengalir bak air sungai mengikuti alurnya. Namun sebaliknya ialah, ada juga karya tulis Buya HAMKA yang sarat dengan pemikiran filsafat, sehingga memerlukan pehaman yang dalam melalui tafsir dan kontemplasi untuk mendapatkan makna.

Aspek ketiga adalah baca, yaitu adanya kesadaran untuk membaca tulisan yang didukung oleh keterampilan membaca berdasarkan takaran kemampuan tertentu untuk kemungkinan ragam isi dan bentuk tulisan. Membaca adalah suatu tindakan yang didukung oleh keterampilan tertentu dan tindakan tersebut pada 
dasarnya adalah tindakan yang disengaja, dipelajari, serta memerlukan waktu tertentu untuk melakukannya. Dalam membangun sistem tulis baca, maka membaca adalah tindakan yang harus dibangun atau ditumbuhkan sejalan dengan membangun aspek yang lain, sehingga terjadi keseimbangan (equilbirium) untuk kehidupan sistem tulis baca itu sendiri. Namun amat disayangkan sampai saat ini, pada umumnya bangsa Indonesia masih jauh tertinggal dalam hal kesadaran membaca apabila dibandingkan dengan bangsa-bangsa lain yang lebih maju.

Dapat dilihat misalnya bangsa Jepang, mereka senantiasa membawa buku bacaan yang siap dibaca kapan terbentuknya keseimbangan peradaban tulis baca meniscayakan tiga unsur yang membentuknya, yaitu isi, tulisan, dan membaca, tumbuh atau ditumbuhkan melalui cara apa saja. Jalur pendidikan yang benar merupakan jalur yang dapat ditempatkan sebagai jalur utama yang memungkinkan tumbuhnya kesadaran betapa pentingnya tulis baca dalam membangun hidup.

Pada akhirnya dapat diambil beberapa pengertian pokok sehubungan dengan pembicaraan mengenai 'tulis baca' ialah, bahwa tulis baca adalah suatu "bentuk" perpaduan pengetahuan dan keterampilan. Eksistensinya menjadi kebutuhan hidup manusia yang hakiki dalam konteks manusia sebagai

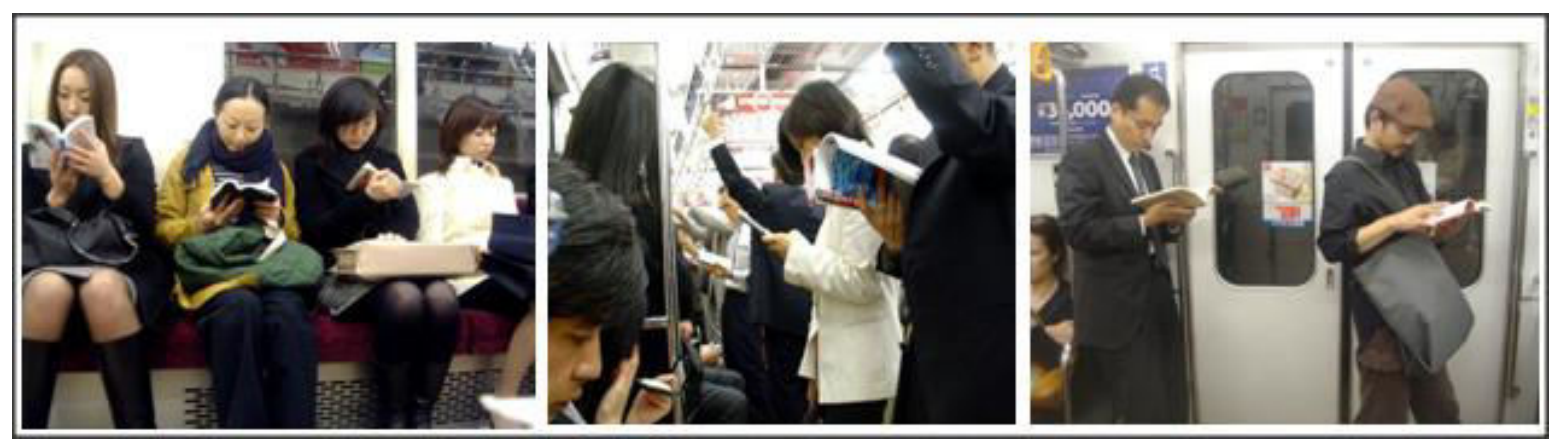

Figure 1. Bangsa Jepang mengisi waktu lowong dengan membaca (Sumber: https://www.google.com/search?q=bangsa+jepang+membaca)

dan di mana saja. Pada umumnya mereka tidak membuang-buang waktu. Waktu kosong atau luang hampir selalu diisi dengan membaca buku yang selalu mereka bawa ke mana-mana. Kondisi begini menyiratkan, bahwa lancar dan makhluk yang paling sempurna. Kehidupan tulis baca pada hakikatnya ialah menghidupkan tindakan memanusiakan manusia dengan segala kelebihannya daripada makhluk lain di muka bumi. Oleh karena itu, tulis baca 
yang dikehendaki dalam rangka memanusiakan manusia yang berharkat dan bermartabat dalam segala aspek kecerdasan, ialah terbangunnya kehidupan manusia sebagaimana kesempurnaannya sebagai manusia. Kesempurnaan manusia dalam kehidupan Islam adalah senantiasa beribadat kepada-Nya dalam rangka menuju kehidupan akhirat.

Tindakan beralur tulis baca yang begitu mendasar perananya untuk membangun hidup dan peradaban manusia seperti tergambar pada latar berdirinya Eropa modern di atas, dilakukan Buya HAMKA sepanjang hayat dengan melahirkan seratusan lebih buku dalam sejumlah disiplin. Sederetan karya tulis sejalan dengan kepiawaian serta jalur hidup yang dijalani seseorang bernama Si Bujang Jauah, "gelar" kesayangan sewaktu remaja yang diberikan Haji Rasul, Syeh Abdul Karim Amrullah ayah tercintanya seperti demikian, menjadikan anak Sungai BatangManinjau itu "besar" dan memang besar..., dengan "Multi Talenta" bernama lengkap Haji Abdul Malik Karim Amrullah yang disingkat HAMKA dan beranugerah gelar Doctor serta Professor.

\section{PENUTUP}

$$
\text { Buya HAMKA telah }
$$
meninggalkan pusaka yang tak ternilai harganya bagi kehidupan bangsa dan negara. Secara biologis tidak ada beda Buya HAMKA dengan manusia lain mana saja, akan tetapi yang membedakan adalah rekam jejak yang ditinggalkan Buya HAMKA sulit ditandingi oleh generasi sampai saat ini. Multi talenta yang hidup pada diri Buya HAMKA merupakan anugerah dari Sang Maha Pencipta diraih melalui kerja keras, hingga berbuah manis sepanjang masa. Lika liku yang ditempuh Buya HAMKA dengan segala onak dan duri sepanjang hidupnya dapat bernilai positif untuk dijadikan suri tauladan dalam rangka menanamkan kesadaran berbuat terbaik untuk membangun hayat. Buya HAMKA telah menunjukkan "Harimau mati meninggalkan belang; Gajah mati meninggalkan gading; Manusia mati meninggalkan jasa; ....... Besar harimau pada belangnya; Besar gajah pada gadingnya”. Seratusan lebih buku berisikan kajian dan buah pikir yang diabadikan Buya HAMKA dalam untai kata dan kalimat nan elok merupakan pusaka yang patut diwarisi dan dijadikan pacu dalam hidup. Begitu 
pula sejumlah karier yang dilakoni Sang Buya dapat menjadi inspirasi untuk menumbuhkan laku-tindak yang berujung kejayaan. Tepatlah Buya HAMKA merupakan sang multi talenta tanah Melayu Nusantara yang patut ditauladani

\section{DAFTAR PUSTAKA}

Al-Faruqi, Ismai'l Raji dan Lois Lamya Al-Faruqi. Atlas Budaya Islam: Menjelajah Khazanah Peradaban Gemilang, Cetakan ke-IV, Terj. Ilyas Hasan dari judul The Cultural Atlas of Islam. Bandung: Mizan, 2003.

Hamka. Ajahku - Cetakan Ketiga. Djakarta: Djajamurni, 1963.

--------. Tafsir Al Azhar - Juzu' 3. Jakarta: PT. Pustaka Panjimas, 1983.

- Tasauf: Perkembangan dan Pemurniannya. Jakarta: Pustaka Panjimas, 1984.

$\begin{array}{lr}\text { Minangkabau. Jakarta: } & \text { Adat } \\ \text { Pustaka Panjimas, } 1984 . & \end{array}$

Rice, Jr., Eugene F. The Foundations of Modern Europe, 1460-1559. New York: W.W. Norton \& Company, 1970.

http://hajibuyahamka.blogspot.com/200 9/07/ ; diunduh pkl. 4:50, tgl. 20-1-2015 http://id.wikipedia.org/wiki; diunduh: pkl. 9:18, tgl. 20-1-2015. http://indosastra.com/sinopsis; diunduh: pkl. 10:18, tgl. 23-1-2015.

http://www.pustakasekolah.com/sinopsi s; diunduh: pkl. 10:38, tgl. 23-1-2015.

https://serbasejarah.wordpress.com; diunduh: pkl. 2:55, tgl. 23-1-2015. https://serbasejarah.wordpress.com; diunduh: pkl. 2:55, tgl. 23-1-2015.
Al-Qur'an Digital Versi 2.1 http://www.alquran-digital.com/ Microsoft® Encarta $® 2006$. (C 19932005 Microsoft Corporation. All rights reserved. 